JOURNAL OF SECURITY AND SUSTAINABILITY ISSUES

ISSN 2029-7017/ISSN 2029-7025 (online)

2020 Volume 9 January

http://doi.org/10.9770/jssi.2020.9.J(15)

Scopus

\title{
DETERMINANTS OF QUALITY EDUCATION IN ASIAN COUNTRIES: IMPACT OF SOCIAL GLOBALIZATION, HAPPINESS AND RESEARCH AND DEVELOPMENT
}

\author{
Kittisak Jermsittiparsert ${ }^{1}$, Thanaporn Sriyakul ${ }^{2 *}$ \\ ${ }^{I}$ Social Research Institute, Chulalongkorn University, Bangkok, Thailand \\ ${ }^{2}$ Faculty of Business Administration, Mahanakorn University of Technology, Bangkok, Thailand \\ E-mails: ${ }^{1}$ kittisak.j@chula.ac.th ; ${ }^{2}$ ajbamut@gtmail.com (Corresponding author)
}

Received 16 March 2019; accepted 16 December 2019; published 30 January 2020

\begin{abstract}
The importance of education has been increasing with the passage of time because of increase in demand of educated people in several sectors of a country. In this regard, the author has selected three aspects i.e. social globalization, happiness and R\&D for the purpose of checking their impact on quality of education in the country. To serve this purpose, the author has gathered data from reliable sources in context of some Asian countries for 27 years and has applied some relative tests and techniques for its analysis. These tests include unit root test, cointegration test and coefficient estimation test. The results of these tests have been presented in different tables present in the study. These results indicate that there is significant impact of happiness, social globalization and per capita income on quality of education, but the impact of happiness and literacy rate are found to be insignificant. After these results, the author has discussed some important implications of the study. Some notable limitations have also been discussed along with the suggestions and recommendations by the author for improvement purposes.
\end{abstract}

Keywords: Quality Education; Social Globalization; Happiness; Research and Development; Asia

Reference to this paper should be made as follows: Jermsittiparsert, K., Sriyakul, T. 2020. Determinants of quality education in Asian countries: impact of social globalization, happiness and research and development, Journal of Security and Sustainability Issues, 9(January), 202-214. http://doi.org/10.9770/jssi.2020.9.J(15)

JEL Classifications: I25

\section{Introduction}

In Asia, there is an age of modern technology, in which information revolution has been realized. In current age, a lot of people have become capable of travelling easily as well as quickly. Social globalization has resulted in making people able to interact with each other. Along with the movement of individuals, new ideas, perceptions and concepts also move from one country to another. Education is something which is considered to be highly important in any country. As a result of social globalization, people get to know about different other people who have different point of views and perceptions (Albion, Tondeur, Forkosh-Baruch, \& Peeraer, 2015; Zeibote, Volkova, Todorov, 2019). As a result of social globalization, the education system of Asian countries has got significantly affected. In order to exploit the key opportunities gained through social globalization and to overcome the key challenges, research and development is considered to be highly important (Ball, 2017). In education sector of Asia, it has become highly important to focus on investing on research and development. Due to the increase in population as a result of social globalization, the demand for education has also got enhanced and this has created a need for management of educational institutions to focus on R\&D activities in order to bring significant improvement within the sector (Bengtsson \& Dryden-Peterson, 2016; Girdzijauskaite, Radzeviciene, Jakubavicius, 2019). (See figure 1 below). 
JOURNAL OF SECURITY AND SUSTAINABILITY ISSUES

ISSN 2029-7017/ISSN 2029-7025 (online)

2020 Volume 9 January

http://doi.org/10.9770/jssi.2020.9.J(15)

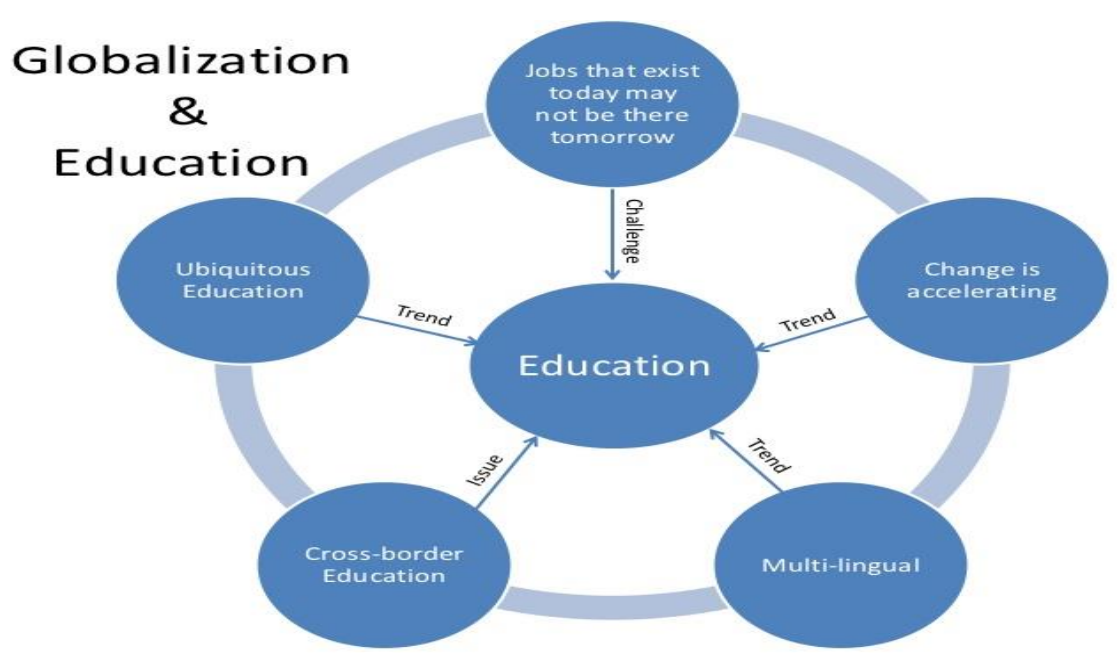

Figure 1. Interrelation between globalization and education

Source: authors

There is a significant impact of globalization on education systems across the globe. In the developing world, the education of young individuals is considered to be a pathway towards growth and prosperity. The internationalization of education has both benefits and disadvantages in social globalization. In the long term, this might prove to be a significant contributor to educational development. However, there are also chances that the social globalization might result in undermining the impact of education on growth of manpower and this might result in over-looking human rights in education (Bengtsson \& Östman, 2016). Hence, there is a need of deeply analyzing the key impact of social globalization on education's quality. In addition to this, due to the increased trend of conducting research and development within education sector in Asian countries, it has become highly important to deeply analyze that whether or not research and development activities play a key role in enhancing quality of education. Coburn and Penuel (2016) claimed that learning as well as creation of knowledge get shaped through social globalization. The internal learning gets influenced through the shift in socio-economic standards, the power of social shifts, political changes and inertia of technological visions. There is an increased dependence of poverty of Asian countries on quality of education. The education's quality is considered to be a key standard for analyzing success of a country. Those countries in which importance of education has been realized are taking proper measures for enhancing the standard of higher education.

However, in case of most of Asian countries, quality of education is not given that much importance. Most of young individuals in Asian countries do not feel happy while getting education in different institutions (Cullingford, 2017). This creates a need for management of educational institutions to focus on identifying key determinants which have an impact on quality of education (Delahunty, Phusavat, Kess, Kropsu-Vehkapera, \& Hidayanto, 2018). On the basis of this, the focus of current study is on examining the impact of social globalization, research and development and happiness on quality of education in Asian context. Previously, there has been no single study conducted for understanding the key impact of these three determinants of quality of education in Asian context.

Hence, this study has filled the gap in literature and along with this, the study is also beneficial for authorities and management of Asian educational institutions. This is due to the fact that they can get an understanding about key determinants which must be focused for ensuring high quality education. The study is based on following key objectives; 


\section{JOURNAL OF SECURITY AND SUSTAINABILITY ISSUES}

ISSN 2029-7017/ISSN 2029-7025 (online)

2020 Volume 9 January

http://doi.org/10.9770/jssi.2020.9.J(15)

- To examine the impact of social globalization on quality of education.

- To study the influence of research and development on quality of education.

- To analyze the impact of happiness on quality of education.

This research paper has been divided in to five main parts, among which, the most initial section in Introduction, in which key background, rationale, problem statement, research objectives and significance are given. The second chapter is about critical review of literature and after this, methodology section is given. The last chapter is conclusion in which conclusion, limitations and recommendations are given.

2. Literature Review

a. Social Globalization and Quality of Education

There is a close relation of social globalization with education. Education plays an important role in shaping a society and it is important to have some connection between globalization and education. The social globalization activities have a deep impact on education sector of a country (Dobbins \& Kwiek, 2017). As a result of social globalization, an increased emphasize on internationalization on subjects. Along with this, it also creates opportunities for new partnerships especially in teaching with different agencies as well as institutions all across the globe. This assists in bringing overall improvement in quality of education (Kogan, 2018). Globalization is considered as a powerful force, which has resulted in bringing transformation in basis of business competition. As a result of social globalization, local communities of practices have moved towards a prominent structure form. The focus of communities in practice in case of social globalization is on building, sharing and applying competencies needed for competing in a knowledge-based economy (Kruss, McGrath, Petersen, \& Gastrow, 2015). According to Kubanyiova and Crookes (2016) in almost every country across the globe, there is a continuous change, which needs to be managed properly. As a result of social globalization, educational sector has to face new social, cultural and economic challenges. In the field of education, there are a number of changes, which need to be adjusted properly in this world of social globalization (Lee \& Gopinathan, 2018). As a result of social globalization, the educational institutions have to focus on responding to social change and they have to focus on implementing expectations of society (Norton, 2018). In addition to this, Pais and Costa (2017) found that future universities will not only for young individuals. Rather than this, people belonging to all ages will be able to get education and all educational institutions will be open to them. Any person who has a motivation of learning and has the capability of noticing issues with the help of social experiences can get education (Rautalin, Alasuutari, \& Vento, 2019). Moreover, Robertson and Dale (2015) claimed that there is an expectation that number of students will be increased in future and this will result in creation of a different academic environment. Besides this, there are also chances that the availability of graduate students will be increased, during economic and social changes. Hence, it is highly important for universities as well as other educational institutions to contribute to community from abroad longterm perspective. It has been argued by Rozhenkova and Rust (2018) that education in terms of social globalization also implies and it is important to teach students that global education is not viewed by everyone in this world as indifferent (Oldfield \& Baron, 2000; Ossiannilsson, Williams, Camilleri, \& Brown, 2015; Patrinos, 1990). Some individuals may consider it as vehicle for growth of globalization. On the basis of this review, following hypothesis is formed;

H1: There is a significant impact of social globalization on quality of education in Asia.

\section{b. Research \& Development and Quality of Education}

In order to ensure growth and development of education sector, it is important to make investment in research and development. It is highly important for ensuring competitiveness of an economy as well as state development on long term basis. Investment in science as well as development is set as key priority as per national policy planning documents (Holm, Sammalisto, \& Vuorisalo, 2015; Voogt \& Knezek, 2016). However, there is non-availability of enough finance for such types of activities in Asian countries (Schuster, Jörgens, \& Kolleck, 2019). In an education sector, the amount of $R \& D$ investment is considered as a key factor which can be used to gain scientific indicators. 
JOURNAL OF SECURITY AND SUSTAINABILITY ISSUES

ISSN 2029-7017/ISSN 2029-7025 (online)

2020 Volume 9 January

http://doi.org/10.9770/jssi.2020.9.J(15)

Their promotion can be ensured through granting funds and financial resources in an efficient manner (Tattum \& Tattum, 2017). In different national research systems, it is important to focus on promoting science funding's efficiency, while overcoming challenges linked with globalization and ensuring high quality. This requires bringing significant changes in science structures as well as methodology in giving finances (Shields, 2016). Moreover, Silova and Rappleye (2015) argued that there is also an importance of kind of granting financing, on the basis of which more financing is granted on the basis of models, which are based on achievement of goals. It is important for management of educational institutions to ensure considerable spending on research and development activities (Gong \& Yi, 2018; Olasupo \& Idemudia, 2017).

According to Thomas (2017) in order to ensure high efficiency and effectiveness of R\&D activities, it is important to ensure strong cooperation between various sectors involved in such activities. Moreover, there is an increased importance of R\&D grant fellowships, which are designed for providing resources for advancement of research. This can provide a number of key benefits to students, as they can get opportunity of carving their own research and developing leadership as well as independence. In an education sector, the resources provided to students and the legitimacy conferred through securing a competitive grant can be used as a mechanism of positive feedback and it can help in socializing the student deeply in to the field and sparking further research productivity (Wu, 2019). In addition to this, Yemini, Goren, and Maxwell (2018) argued that as per organizational standpoint, financial autonomy for graduate students can help in adding advantages for their institution, as availability of internal funds can be used for funding students in R\&D projects.

H2: There is a significant impact of research and development (R\&D) on quality of education in Asia.

\section{c. Happiness and Quality of Education}

Teachers are the most important stakeholders within the education sector of any country. Teachers have the responsibility of providing quality education to their students. The successful learning by students depends on ability of teachers. Happiness is something which is highly important within the field of education (Zajda, 2015). Being providers of education, teachers have to be happy, because their happiness and satisfaction level has a positive impact on students' learning (Zajda, 2018). According to Zajda and Ozdowski (2016), in order to ensure the provision of high quality education, it is important for authority and management of educational institutions to keep their teachers satisfied, happy and motivated. It has been argued by Coburn and Penuel (2016) that the satisfaction level of teachers as well as authoritative persons play a key role in bringing improvement in the quality of education. On the basis of this, following hypothesis is formulated;

\section{H3: There is a significant impact of happiness on quality of education in Asia.}

\section{Methodology}

\section{a. Data}

For any research, data collection is a very crucial and important step as the results are completely based the quality and authenticity of the collected data. Therefore the author has put great efforts while collecting data and has involved the variables such as quality of education, social globalization, happiness and research and development R\&D. Along with these variables, the author has also taken two other variables i.e. literacy rate and per capita income as the control variables. In this regard, some of the Asian countries have been selected for data gathering and the period for which data is collected comprises of 27 years. The data has been collected from reliable and accurate databases or sources such as World Bank and Global Economy. After collection of data, the author has mentioned and defined all the variables in accordance with their measurement units. 
JOURNAL OF SECURITY AND SUSTAINABILITY ISSUES

ISSN 2029-7017/ISSN 2029-7025 (online)

2020 Volume 9 January

http://doi.org/10.9770/jssi.2020.9.J(15)

\section{b. Model Specification}

The current study has the main objective of exploring the impact of social globalization, happiness and R\&D on the quality of education in Asian countries. This objective can be achieved by collecting data and applying various tests on them. But prior to that, a regression equation has to be generated by the author. For this purpose, the author has identified some measurement units for all the variables that have been used in this study. The independent variables include social globalization, happiness and R\&D while the dependent variable of this study is quality of education. In addition to these variables, two control variables i.e. per capita income and literacy rate have also been included. The measurement unit of quality of education EDU is the satisfaction level of the students getting education. The measurement unit of social globalization GLOB is based on an index that ranges from zero to hundred. The measurement unit of happiness HAPP is also based on an index, happiness index that ranges from zero to ten. The measurement unit of $R \& D$ is taken in sense of $R \& D$ expenditure, which is taken as the percentage of the GDP used for R\&D. The measurement unit of per capita income PCI is million US dollars while that of literacy rate LIT is percentage of people that are educated in a country. A regression equation can be built and is given as:

$$
E D U_{i t}=\alpha+\beta_{1} G L O B_{i t}+\beta_{2} H A P P_{i t}+\beta_{3} R \& D_{i t}+\beta_{4} L I T_{i t}+\beta_{5} P C I_{i t}+\varepsilon_{i t}
$$

In the above given equation, EDU is education quality, GLOB is social globalization, HAPP is happiness, R\&D is research and development, LIT is literacy rate, PCI is per capita income and $\varepsilon_{i t}$ is the term that expresses error.

\section{c. Estimation Procedure}

Once data has been collected and regression equation has been made, the next phase in which the gathered data enters is the estimation phase in which several tests and approaches are applied in order to investigate different properties and characteristics of data. In this study, the author has employed LLC unit root test, Kao cointegration test and DOLS coefficient estimation test for data analysis purpose, the details of which are discussed here:

\section{i. Panel Unit Root Test}

In the estimation procedure of data, the first step is to find out the order of integration of the variables along with their stochastic properties. This is necessary as order of integration is a crucial aspect that allows the right data to enter the next phase of the research and in this way avoids any wrong and misleading results (Levin, Lin, \& Chu, 2002). The unit root test has been designed for this particular purpose. The unit root tests that are more commonly used for the same purpose include LLC (homogeneous autoregressive process) and IPS (heterogeneous autoregressive process) unit root tests. Both the tests have one thing in common i.e. their results are based on null and alternate hypotheses. The presence of unit root and non-stationary state of data indicates the null hypothesis while absence of unit root and stationary state of the data indicates alternate hypothesis. These two hypotheses are the base on which the whole evaluation of the results of unit test are based. Based on the type of data in the study, the author has chosen LLC unit root test and its general equation is presented as:

$$
\Delta y_{i, t}=a_{i}+\rho y_{i, t}-1+\sum_{J=1}^{p i} a_{J} \Delta y_{i, t-J}+\varepsilon_{i, t}
$$

Here $\Delta y_{i, t}$ is the difference that $\Delta y_{i, t}$ shows for $\mathrm{i}^{\text {th }}$ country for the specific time period of $\mathrm{t}$.

\section{ii. Panel Cointegration Test}

Once the order of integration and stationery and non-stationary state of the variables has been identified, the author then moves towards the investigation of cointegrated or long run relationships between the variables. This purpose can be achieved by using the cointegration tests, the most commonly used of which include Kao and Pedroni cointegration tests. However the author has adopted the Pedroni cointegration test in this particular study (Im, 
JOURNAL OF SECURITY AND SUSTAINABILITY ISSUES

ISSN 2029-7017/ISSN 2029-7025 (online)

2020 Volume 9 January

http://doi.org/10.9770/jssi.2020.9.J(15)

Pesaran, \& Shin, 2003). Studies have shown that cointegration tests include two approaches i.e. within dimension approach and between dimension approach. Within dimension approach involves four test statistics values while the between approach involves three test statistics values. These test values are linked with the acceptance and rejection of null and alternate hypotheses. The null hypothesis involves that there is no cointegration among the variables while alternate hypothesis involves that there is cointegration between the same variables. By evaluating the acceptance or rejection of these hypotheses, the results of cointegration tests can be evaluated and interpreted. In this scenario, when most of the variables or all the variables have rejected the null hypothesis, this means that there is cointegrated relationship between variables and vice versa. The author has used the Kao cointegration test and has adopted the following equation for this purpose:

$$
y_{i, t}=\alpha_{i}+\delta_{i, t}+\beta_{1} X_{1, i, t}+\beta_{2} X_{2, i, t}+\cdots+\beta_{n} X_{n, i, t}+\varepsilon_{i, t}
$$

\section{iii. Coefficient Estimation Test}

In the estimation procedure, after the exploration of order or integration and presence of cointegrated relationships between the variables, the next step is usually to measure these relationships through the estimation of coefficients of different independent and control variables. For this purpose, coefficient estimation techniques are usually used. The most important and commonly used coefficient estimation techniques include FMOLS and DOLS (Pedroni, 2001). These are the modified forms of simple OLS test that actually caused some serial correlation and endogenous variables issues. These issues caused misleading results of these tests. Therefore, to resolve these issues, FMOLS and DOLS were developed from OLS. The author has used DOLS estimation test in this particular study. By measuring the coefficients of various variables, the magnitude of impact can easily be measured in context of quality of education. The significance values of these coefficients of variables have special importance in this regard. The significance value may be one percent, five percent or ten percent as presented by the *, **, *** respectively. The author has used the following equation for this test:

$$
\hat{\beta}_{F M}=\left(\sum_{i=1}^{N} \sum_{t=1}^{T}\left(x_{i, t}-\bar{x}_{i}\right)^{2}\right)^{-1} \sum_{i=1}^{N}\left(\sum_{t=1}^{T}\left(x_{i, t}-\bar{x}_{i}\right) \widehat{E D U}_{i, t}-T \hat{\delta}_{\varepsilon u}\right)
$$

In this equation, $\widehat{E D U}_{i, t}$ is the transformed variable of quality of education due to endogeneity correction while $\hat{\delta}_{\varepsilon u}$ represents the serial correlation correction by FMOLS.

\section{Empirical Analysis}

a. Results of Panel Unit Root Test

The author has used LLC unit root test in order to find out the order of cointegration of the variables as well as the stationarity of these variables as discussed in the earlier section of the study. After the application of this test, the author has received the results as presented in table 1 given below. According to this table, in level section, happiness level of the people and literacy rate in a country has rejected the null hypothesis but all other variables have accepted the null hypothesis. This indicates the fact that in level section of the table, the unit root is present but the data is non stationary. When this series is first differenced, it can be evidently seen that all of the selected variables have rejected the null hypothesis. This leads towards the shift of non-stationary state of the data collected to stationary state. Thus as discussed above, the acceptance and rejection of null hypothesis has major role in the final evaluation of unit root test results, which can be concluding by stating that data in level series is non stationary and it shifts to stationary state when first difference is applied to it. 
JOURNAL OF SECURITY AND SUSTAINABILITY ISSUES

ISSN 2029-7017/ISSN 2029-7025 (online)

2020 Volume 9 January

http://doi.org/10.9770/jssi.2020.9.J(15)

Table 1. Panel Unit Root Test - Levin Lin Chu LLC

\begin{tabular}{lll}
\hline Variable & Level & $1^{\text {st }}$ Difference \\
\hline \multirow{2}{*}{ EDU } & -6.2947 & $-2.2846^{* * *}$ \\
& $(0.252)$ & $(0.003)$ \\
GLOB & -6.5863 & $-4.2947^{* *}$ \\
& $(0.826)$ & $(0.014)$ \\
HAPP & $-7.1936^{* *}$ & $-9.1312^{* * *}$ \\
& $(0.476)$ & $(0.001)$ \\
R\&D & -5.4962 & $-9.3442^{* * *}$ \\
& $(0.528)$ & $(0.000)$ \\
PCI & -8.2745 & $-10.919^{* *}$ \\
& $(0.482)$ & $(0.005)$ \\
LIT & $-6.2846 * *$ & $-11.727^{* * *}$ \\
\hline
\end{tabular}

In this table, $*$ represents that the rejection is one percent significant, ** shows that rejection is five percent significant, *** shows that rejection is ten percent significant

\section{i. Results of Panel Cointegration Test}

After getting results of unit root test, the author then applied Kao cointegration test and got the results presented in table 2 of this study. The presence of within dimension and between dimension approach has been very evident in the table presented below. As the matter of fact, two test statistic values from each within dimension approach and between dimension approach have rejected the null hypothesis of no cointegration.

As the null hypothesis suggested that there is no cointegrated relationship between the variables that have been under study, therefore it can be stated that the rejection of null hypothesis by four out of total seven test statistics values from within and between approaches will lead towards the fact the cointegrated relationships do occur among the variables of the study.

If majority of the variables have accepted the null hypothesis, this would ultimately lead towards the fact that no cointegrated relationships or long run relationships are present among the variables. Therefore, the results of this test can be concluded in such a way that as most of the variables have rejected the null hypothesis, it points towards the absence of any long run cointegration between the variables. 
JOURNAL OF SECURITY AND SUSTAINABILITY ISSUES

ISSN 2029-7017/ISSN 2029-7025 (online)

2020 Volume 9 January

http://doi.org/10.9770/jssi.2020.9.J(15)

Table 2. The KAO Panel Cointegration Test

$\begin{array}{lllll}\text { Alternative hypothesis: common AR coefs. (within-dimension) } & & & \\ & & & \text { Weighted } & \underline{\text { Prob. }} \\ & \underline{\text { Statistic }} & \text { Prob. } & \underline{\text { Statistic }} & 0.0002 \\ \text { Panel v-Statistic } & -3.846838 & 0.4836 & -6.382684 & 0.7352 \\ \text { Panel rho-Statistic } & 3.983684 & 0.2836 & 3.384683 & 0.0003 \\ \text { Panel PP-Statistic } & -22.28468^{*} & 0.0003 & -5.284648 & 0.0005\end{array}$

Alternative hypothesis: individual AR coefs. (between-dimension)

$\begin{array}{lll} & \underline{\text { Statistic }} & \underline{\text { Prob. }} \\ \text { Group rho-Statistic } & 6.284783^{*} & 0.0000 \\ \text { Group PP-Statistic } & -21.28483 & 0.0000 \\ \text { Group ADF-Statistic } & -2.846856^{* *} & 0.0253\end{array}$

In this table, $*$ represents that the rejection is one percent significant, $* *$ shows that rejection is five percent significant

\section{ii. Results of Coefficient Estimation Test}

After the application of unit root test and cointegration test on the collected data and receiving all the related results from these tests, as the next step, the author has adopted DOLS estimation test in order to measure the relationship that is found to exist among the variables. The detailed results of DOLS test have been given in table 3 of the study. In this table, it has been observed by the author that the values of social globalization, $R \& D$ expenditure and the control variable per capita income are significant, and this significance shows that the impact of these variables is significant in context of quality of education. These significance levels are ten percent, five percent and one percent respectively and it can be explained in another was as follows. With the increase in one percent of social globalization, the quality of education will increase by $29.6 \%$, with one percent increase in R\&D expenditure, the quality of education will increase by $29.4 \%$, with one percent increase in per capita income, the quality of education will increase by $3.8 \%$ in a country. Apart from these variables, happiness and literacy rate have been found to have insignificant impacts on quality of education.

Table 3. DOLS Regression

\begin{tabular}{lllll}
\hline Variable & Coefficient & Std. Error & t-Statistic & Prob. \\
\hline GLOB & $0.296482 * * *$ & 0.3826 & 3.947628 & 0.0023 \\
HAPP & 0.394682 & 0.3752 & 4.236883 & 0.0012 \\
R\&D & $0.294764 * *$ & 0.8467 & 4.283648 & 0.0001 \\
PCI & $0.038368^{*}$ & 0.2746 & 1.284682 & 0.3846 \\
LIT & 0.284682 & 0.2736 & 2.493782 & 0.0021
\end{tabular}


JOURNAL OF SECURITY AND SUSTAINABILITY ISSUES

ISSN 2029-7017/ISSN 2029-7025 (online)

2020 Volume 9 January

http://doi.org/10.9770/jssi.2020.9.J(15)

\begin{tabular}{|c|c|c|c|c|}
\hline Constant & 0.183648 & 0.2868 & 3.198374 & 0.00054 \\
\hline R-squared & 0.846384 & & & \\
\hline Adjusted R-squared & 0.375482 & & & \\
\hline F-statistic & 12.38462 & & & \\
\hline Prob(F-statistic) & 0.000000 & & & \\
\hline Durbin-Watson stat & 2.286482 & & & \\
\hline
\end{tabular}

5. Discussion and Conclusion

\section{a. Discussion}

As it has been very clear that the main motive behind this study was to find out the impact of social globalization, $\mathrm{R} \& \mathrm{D}$ and happiness of people on quality of education along with the presence of two control variables literacy rate and per capita income, some hypotheses were generated by the author in this study. The first hypothesis of impact of social globalization on quality of education has been accepted as significant which is in accordance of the past study (Giulianotti \& Robertson, 2007). The next hypothesis in this regard was that the impact of happiness on quality of education is significant and this hypothesis has been rejected by the results. This situation is in accordance with the previous study (Easterlin, 2003). The last hypothesis was that R\&D has significant impact on quality of education. The author has accepted this hypothesis too in accordance with the results and a past study (Reinganum, 1989). In the last, the control variable, per capita income is also found to have significant impact on quality of education which is in concordance with a study that has been conducted in the past (Krueger, 1968).

\section{b. Conclusion}

Happiness level of people, R\&D expenditure and social globalization are very important aspects and they have a connection with quality of education in a country. As a matter of fact, this study has been conducted in order to explore the impact of these three aspects on quality of education for which the data was collected from different Asian countries for 27 years. This data was collected from reliable databases and different approaches were run on that data for analysis purpose. The results of these approaches suggested that social globalization, R\&D and per capita income have significant impacts on quality of education in a country. Several implications as well as limitations have been discussed by the author in the last section of the study.

\section{c. Implications}

The author has mentioned some of the most notable implications and benefits that are associated with this study. First of all, this study provides literature about the important concepts such as social globalization, happiness and $\mathrm{R} \& \mathrm{D}$ and their impacts on quality of education. This is an important source of information for the researchers and other authors. Other than this, this study will also provide assistance to the education related departments and officials to improve the conditions of social globalization, happiness levels and R\&D expenditures so that they may be used to improve the quality of education. In the last, this study will also provide guidance to the government departments to make policies and regulations that are suitable for education and promote it along with other related factors. 
JOURNAL OF SECURITY AND SUSTAINABILITY ISSUES

ISSN 2029-7017/ISSN 2029-7025 (online)

2020 Volume 9 January

http://doi.org/10.9770/jssi.2020.9.J(15)

\section{d. Limitations and Future Research Indications}

Several limitations have been discussed by the author in context of this study and some recommendations have also been discussed which can be beneficial for the other researchers. The first limitation in this regard is that the sample size is very small which may be increased by other researchers. This study has been conducted only in context of Asian countries while other researchers may move to other countries or groups for research purposes. They may also use variables that have not been included in this particular study or they may change the combination of these variables. They may also use tests or approaches that have not been used by the author in this particular study.

\section{References}

Albion, P. R., Tondeur, J., Forkosh-Baruch, A., \& Peeraer, J. (2015). Teachers' professional development for ICT integration: Towards a reciprocal relationship between research and practice. Education and Information Technologies, 20(4), 655-673.

http://dx.doi.org/10.1007/s10639-015-9401-9

Ball, S. J. (2017). The education debate: Policy Press.

Bengtsson, S. E., \& Dryden-Peterson, S. (2016). Education, conflict, and globalization: Guest Editors' introduction: Taylor \& Francis. https://doi.org/10.1080/14767724.2016.1189203

Bengtsson, S. L., \& Östman, L. O. (2016). Globalization and education for sustainable development: exploring the global in motion. Environmental Education Research, 22(1), 1-20. https://doi.org/10.1080/13504622.2012.709822

Coburn, C. E., \& Penuel, W. R. (2016). Research-practice partnerships in education: Outcomes, dynamics, and open questions. Educational Researcher, 45(1), 48-54. https://doi.org/10.3102\%2F0013189X16631750

Cullingford, C. (2017). Globalization as education? Images of other countries Globalization, education and culture shock (pp. 21-34): Routledge.

Delahunty, D., Phusavat, K., Kess, P., Kropsu-Vehkapera, H., \& Hidayanto, A. N. (2018). Globalization and education: case demonstration and lessons learned from Finland's education export. International Journal of Management in Education, 12(1), 25-42.

https://doi.org/10.1504/IJMIE.2018.088370

Dobbins, M., \& Kwiek, M. (2017). Europeanisation and globalization in higher education in Central and Eastern Europe: 25 years of changes revisited (1990-2015): SAGE Publications Sage UK: London, England. https://doi.org/10.1177\%2F1474904117728132

Easterlin, R. A. (2003). Explaining happiness. Proceedings of the National Academy of Sciences, 100(19), 11176-11183.

https://doi.org/10.1073/pnas.1633144100

Giulianotti, R., \& Robertson, R. (2007). Recovering the social: globalization, football and transnationalism. Global networks, 7(2), 166186. https://doi.org/10.1111/j.1471-0374.2007.00163.x

Girdzijauskaite, E., Radzeviciene, A., Jakubavicius, A. (2019). Impact of international branch campus KPIs on the university competitiveness: FARE method. Insights into Regional Development, 1(2), 171-180. https://doi.org/10.9770/ird.2019.1.2(7)

Gong, T., \& Yi, Y. (2018). The effect of service quality on customer satisfaction, loyalty, and happiness in five Asian countries. Psychology \& Marketing, 35(6), 427-442. https://doi.org/10.1002/mar.21096

Holm, T., Sammalisto, K., \& Vuorisalo, T. (2015). Education for sustainable development and quality assurance in universities in China and the Nordic countries: a comparative study. Journal of cleaner production, 107, 529-537. https://doi.org/10.1016/j.jclepro.2014.01.074

Im, K. S., Pesaran, M. H., \& Shin, Y. (2003). Testing for unit roots in heterogeneous panels. Journal of econometrics, 115(1), 53-74. https://doi.org/10.1016/S0304-4076(03)00092-7 


\section{JOURNAL OF SECURITY AND SUSTAINABILITY ISSUES}

ISSN 2029-7017/ISSN 2029-7025 (online)

2020 Volume 9 January

http://doi.org/10.9770/jssi.2020.9.J(15)

Kogan, M. (2018). Educational policy-making: A study of interest groups and parliament: Routledge.

Krueger, A. O. (1968). Factor endowments and per capita income differences among countries. The economic journal, 78(311), 641-659. https://doi.org/10.2307/2229388

Kruss, G., McGrath, S., Petersen, I.-h., \& Gastrow, M. (2015). Higher education and economic development: The importance of building technological capabilities. International Journal of Educational Development, 43, 22-31. https://doi.org/10.1016/j.ijedudev.2015.04.011

Kubanyiova, M., \& Crookes, G. (2016). Re-envisioning the roles, tasks, and contributions of language teachers in the multilingual era of language education research and practice. The Modern Language Journal, 100(S1), 117-132. https://doi.org/10.1111/modl.12304

Lee, M. H., \& Gopinathan, S. (2018). Fostering economic competitiveness, national identity and social equity through education reforms: The cases of Singapore and Hong Kong Globalization and Education Reforms (pp. 181-203): Springer. https://doi.org/10.1007/978-

Levin, A., Lin, C.-F., \& Chu, C.-S. J. (2002). Unit root tests in panel data: asymptotic and finite-sample properties. Journal of econometrics, 108(1), 1-24. https://doi.org/10.1016/S0304-4076(01)00098-7

Norton, L. (2018). Action research in teaching and learning: A practical guide to conducting pedagogical research in universities: Routledge. https://doi.org/10.4324/9781315147581

Olasupo, M. O., \& Idemudia, E. S. (2017). Socio-economic and socio-demographic determinants of quality of life among young adults in South West Nigeria. Gender and Behaviour, 15(4), 9997-10009.

Oldfield, B. M., \& Baron, S. (2000). Student perceptions of service quality in a UK university business and management faculty. Quality Assurance in education, 8(2), 85-95. https://doi.org/10.1108/09684880010325600

Ossiannilsson, E., Williams, K., Camilleri, A. F., \& Brown, M. (2015). Quality models in online and open education around the globe. State of the art and recommendations: Oslo: International Council for Open and Distance Education.

Pais, A., \& Costa, M. (2017). An ideology critique of global citizenship education. Critical Studies in Education, 1-16. https://doi.org/10.1080/17508487.2017.1318772

Patrinos, H. A. (1990). The privatization of higher education in Colombia: Effects on quality and equity. Higher Education, 20(2), 161-173. https://doi.org/10.1007/BF00143699

Pedroni, P. (2001). Fully modified OLS for heterogeneous cointegrated panels Nonstationary panels, panel cointegration, and dynamic panels (pp. 93-130): Emerald Group Publishing Limited. https://doi.org/10.1016/S0731-9053(00)15004-2/full/html

Rautalin, M., Alasuutari, P., \& Vento, E. (2019). Globalization of education policies: does PISA have an effect? Journal of Education Policy, 34(4), 500-522. https://doi.org/10.1080/02680939.2018.1462890

Reinganum, J. F. (1989). The timing of innovation: Research, development, and diffusion. Handbook of industrial organization, 1, 849908. https://doi.org/10.1016/S1573-448X(89)01017-4

Robertson, S. L., \& Dale, R. (2015). Towards a 'critical cultural political economy'account of the globalising of education. Globalization, Societies and Education, 13(1), 149-170. https://doi.org/10.1080/14767724.2014.967502

Rozhenkova, V., \& Rust, V. D. (2018). Internationalization of Higher Education in Russia: Aiming for Global Recognition Globalization and Education Reforms (pp. 93-106): Springer. https://doi.org/10.1007/978-

Schuster, J., Jörgens, H., \& Kolleck, N. (2019). The rise of global policy networks in education: analyzing Twitter debates on inclusive education using social network analysis. Journal of Education Policy, 1-21. https://doi.org/10.1080/02680939.2019.1664768

Shields, R. (2016). Reconsidering regionalisation in global higher education: student mobility spaces of the European Higher Education Area. Compare: A Journal of Comparative and International Education, 46(1), 5-23. https://doi.org/10.1080/03057925.2014.884348 


\section{JOURNAL OF SECURITY AND SUSTAINABILITY ISSUES ISSN 2029-7017/ISSN 2029-7025 (online) \\ 2020 Volume 9 January \\ http://doi.org/10.9770/jssi.2020.9.J(15)}

Silova, I., \& Rappleye, J. (2015). Beyond the world culture debate in comparative education: critiques, alternatives and a noisy conversation: Taylor \& Francis. https://doi.org/10.1080/14767724.2014.967482

Tattum, D., \& Tattum, E. (2017). Social education and personal development: Routledge. https://doi.org/10.4324/9781315201689

Thomas, E. (2017). Globalization, cultural diversity and teacher education Globalization, education and culture shock (pp. 152-170): Routledge.

Voogt, J., \& Knezek, G. (2016). Guest Editorial: Technology enhanced quality education for all-outcomes from EDUsummIT 2015. Journal of Educational Technology \& Society, 19(3), 1-4.

$\mathrm{Wu}$, J. (2019). Confucian revival and the hybrid educational narratives in contemporary China: a critical rethinking of scale in globalization and education. Globalization, Societies and Education, 17(4), 474-488. https://doi.org/10.1080/14767724.2018.1558048

Yemini, M., Goren, H., \& Maxwell, C. (2018). Global citizenship education in the era of mobility, conflict and globalization: Taylor \& Francis. https://doi.org/10.1080/00071005.2018.1533103

Zajda, J. (2015). Globalization, ideology and politics of education reforms Globalization, ideology and politics of education reforms (pp. 153-162): Springer. https://doi.org/10.1007/978-3-319-19506-3_11

Zajda, J. (2018). Globalization and education reforms: Paradigms and ideologies Globalization and Education Reforms (pp. 1-14): Springer. https://doi.org/10.1007/978-94-024-1204-8_1

Zajda, J., \& Ozdowski, S. (2016). Globalization, Human Rights Education and Reforms (Vol. 17): Springer.

Zeibote, Z., Volkova, T., Todorov, K. (2019). The impact of globalization on regional development and competitiveness: cases of selected regions. Insights into Regional Development, 1(1), 33-47. https://doi.org/10.9770/ird.2019.1.1(3) 
JOURNAL OF SECURITY AND SUSTAINABILITY ISSUES

ISSN 2029-7017/ISSN 2029-7025 (online)

2020 Volume 9 January

http://doi.org/10.9770/jssi.2020.9.J(15)

Kittisak JERMSITTIPARSERT_holds Ph.D. in Social Sciences from Kasetsart University, Thailand. He currently is a Researcher at Chulalongkorn University Social Research Institute, a part-time Researcher at Ton Duc Thang University, and the Secretary General of Political Science Association of Kasetsart University. His areas of expertise are Political Science, Public and Business Administration, International Political Economy, and Interdisciplinary Research in Social Sciences.

Thanaporn SRIYAKUL holds Ph.D. in Social Sciences from Kasetsart University, Thailand. He is currently is an Assistant Professor of Management Department, Faculty of Business Administration, Mahanakorn University of Technology, Thailand. His areas of expertise are Politics, Public Administration, Public Policy, and Social Sciences Research.

ORCID ID: orcid.org/0000-0002-9667-3730

Register for an ORCID ID:

https://orcid.org/register

This work is licensed under the Creative Commons Attribution International License (CC BY).

http://creativecommons.org/licenses/by/4.0/

c) (i) Open Access 